\title{
SEXUAL BEHAVIOR AND KNOWLEDGE LEVEL OF COMMERCIAL SEX WORKERS INFLUENCE THE SPREAD OF SEXUALLY TRANSMITTED INFECTIONS
}

Rochman Mujayanto ${ }^{*}$,Erdianto Setya Wardhana ${ }^{* *}$

Keywords:
Commercial Sex
Workers, Sexually
Transmitted
Infections, Oral
Cavity Lesions

INTRODUCTION

The lifestyle of commercial sex workers (CSWs) who are always changing partners is a very high risk of sexually transmitted infections (STIs) caused by bacteria or viruses. The enhancement of STIs can be influenced by several factors one of which is knowledge of how the STIs are transmitted, types of STIs and signs of symptoms if a person is exposed to STIs can affect sexual behavior. . $^{1,3,4} \mathrm{STI}$ is a disease caused by unsafe sexual intercourse, which transmits or be transmitted to their partners. STI does not only cause symptoms in the genital area but can manifest in the oral cavity. IMS manifestations in the oral cavity can be Necrotic ulcerative gingivitis, necrotic ulcerative periodontitis, linear gingival erythe- ma, oral candidiasis, condyloma acuminate, Kaposi sarcoma, non-Hodgkin's lymphoma, oral hairy leukoplakia, gonococcal stomatitis, chancre, snail tracks, gumma. 5,6,7,8

The number of STI cases in Central Java in 2015 was 14.302 cases, higher than in 2013 which was 10.479 cases. The number of STI cases in Semarang was 2.461 cases higher than other cities in Central Java. ${ }^{9}$ Resocialization Argorejo was the largest resocialization in Semarang City spread from alley 1 to alley 6 . Based on preliminary survey research at the non-governmental organization "Lentera Asa" Semarang in December 2017, there were around 488 prostitute women who were at the Argorejo Resocialization. ${ }^{10}$

The author conducted research on sexual behavior and the level of knowledge about

${ }^{*}$ Department of Oral Medicine, Faculty of Dentistry, Sultan Agung Islamic University, Semarang - Indonesia, ${ }^{* * D e-}$ partment of Public Dental Health, Faculty of Dentistry, Sultan Agung Islamic University, Semarang - Indonesia Korespondensi: erdianto.wardhana@unissula.ac.id 
STIs as a risk factor for oral lesions on CSWs in Argorejo Resocialization Semarang.

\section{METHOD}

This research is an analytic survey research with a cross-sectional study approach. This research was conducted in July 2018 at the Argorejo Resocialization of Semarang on Jalan Argorejo, Kalibanteng Kulon, West Semarang. This study was approved by the Health and Medical Research Ethics Commission of the Faculty of Dentistry, Sultan Agung Islamic University, Semarang No 018 / B.1-KEPK / SA-FKG / IV / 2018. The population in this study were commercial sex workers who settled in the Semarang Sunan Kuning localization of 488 people. The sampling technique of this study was simple random sampling. The large sample formula of this study used the Slovin formula so that after the calculation of the sample size obtained is 220 respondents. Measuring instruments in this study are ques- tionnaires that have been tested for validity using the corrected item-total correlation test and the reliability test using the Cronbach alpha test. Data collection of oral cavity lesions by clinical examination using a mouth glass and assisted irradiation using LED ring light then lesions were recorded in the oral cavity of the subject and documented using a camera. After the data is collected univariate and bivariate statistical data were analyzed.

\section{RESULT}

The sample in this study obtained as many as 110 respondents which should have a minimum sample size of 220 respondents. This is because only 110 respondents were present and fulfill the criteria. Characteristics of CSWs in Semarang Argorejo Resocialization who were respondents in this study are shown in Table 1. The age of respondents in this study ranged from 19-47 years with an average of $31.8 \pm 7.56$ years. The education of respon-

Table 1 CSWs Demographic Characteristics in Argorejo Resocialization Semarang

\begin{tabular}{lcc}
\hline \multicolumn{1}{c}{ Characteristics } & Frequency & Percentage \\
\hline Current age (years) & & \\
- Min-max & $19-47$ & \\
- Average \pm standard deviasi & $31.8 \pm 7.56$ & \\
\hline Education & & \\
- No Education level & 16 & $14.5 \%$ \\
- Primary School/equivalent & 34 & $30.9 \%$ \\
- Junior High School/equivalent & 36 & $32.7 \%$ \\
- Senior High School/equivalent & 24 & $21.8 \%$ \\
\hline Originated from Semarang City & & \\
- Yes & 58 & $52.7 \%$ \\
- No & 52 & $47.2 \%$ \\
\hline Length of Stay in Semarang city & & \\
- $<1$ year & 28 & $25.4 \%$ \\
- $\geq 1$ year & 50 & $45.4 \%$ \\
- Since born & 32 & $29.0 \%$ \\
\hline
\end{tabular}


Table 2 Univariate Analysis Results of the level of knowledge of CSW about STIs

\begin{tabular}{lcc}
\hline \multicolumn{1}{c}{ Knowledge Level } & Frequency & Precentage \\
\hline - Less & 41 & $(37.3 \%)$ \\
- Good & 69 & $(62.7 \%)$ \\
\hline
\end{tabular}

Table 3 Results of Univariate Analysis of CSW sexual behavior towards clients

\begin{tabular}{lcc}
\hline Behavior towards clients & Frequency & Precentage \\
\hline - Bad & 34 & $(30.9 \%)$ \\
- Good & 76 & $(69.1 \%)$ \\
\hline
\end{tabular}

Table 4 The description of Relationship between CSWs' knowledge of STIs to the incidence of oral cavity lesions

\begin{tabular}{lllrr}
\hline & & \multicolumn{2}{c}{$\begin{array}{c}\text { Oral Cavity Lesions } \\
\text { exist }\end{array}$} & $\begin{array}{r}\text { Do not exiest } \\
\text { Knowledge of STIs }\end{array}$ \\
& Less & Count & 18 & 23 \\
& & \% within Knowledge of STIs & $43.9 \%$ & $56.1 \%$ \\
\cline { 2 - 5 } & good & Count & 26 & 43 \\
& & $\%$ within Knowledge of STIs & $37.7 \%$ & $62.3 \%$ \\
\hline
\end{tabular}

dents was dominated by junior high school/ equivalent level, $32.7 \%$. The number of respondents originating from the city of Semarang and outside the city of Semarang is almost the same, as many as $52.3 \%$ and $47.7 \%$. Most respondents who lived in the city of Semarang for more than 1 year were $45.9 \%$. $62.7 \%$ of respondents had a good level of knowledge about STIs and $37.3 \%$ of respondents with a lack of level of knowledge (Table 2). $69.1 \%$ of respondents had good sexual behavior, while $30.9 \%$ of respondents had bad sexual behavior (Table 3).

Clinical observations of the oral cavity found suspect candidiasis in 28 cases, ulcers in 11 cases, suspect Lining Gingiva Erythema in 3 Table 5 The description of the Relationship between CSW Sexual Behavior to the incidence of oral cavity lesions

\begin{tabular}{lllrr}
\hline & & \multicolumn{2}{c}{$\begin{array}{c}\text { Lesi Rongga Mulut } \\
\text { ada }\end{array}$} & $\begin{array}{r}\text { Mdidak ada } \\
\text { tida }\end{array}$ \\
\hline $\begin{array}{l}\text { Sexual } \\
\text { Behavior }\end{array}$ & Bad & Count & 32 & 2 \\
& & \% within Sexual Behavior & $94.1 \%$ & $5.9 \%$ \\
& Good & Count & 12 & 64 \\
& & \% within Sexual Behavior & $15.8 \%$ & $84.2 \%$ \\
\hline
\end{tabular}
oral hairy leukoplakia in 1 case (Figure 1). Respondents with a lack of knowledge found $43.9 \%$ had oral cavity lesions, while respondents who had a good level of knowledge had oral cavity lesions. Chi-Square test obtained a $p$-value of $0.328(p>0.05)$ showed that there was no difference between lack of knowledge of STIs and good STI knowledge of the occurrence of oral cavity lesions. Respondents with bad sexual behavior were found to have oral cavity lesions as many as $94.1 \%$. While respondents with good sexual behavior showed an oral cavity lesion of $15.8 \%$. Chi-Square test results obtained a $p$-value of 0.00 ( $p>0.05)$ which means that there are significant differ- 

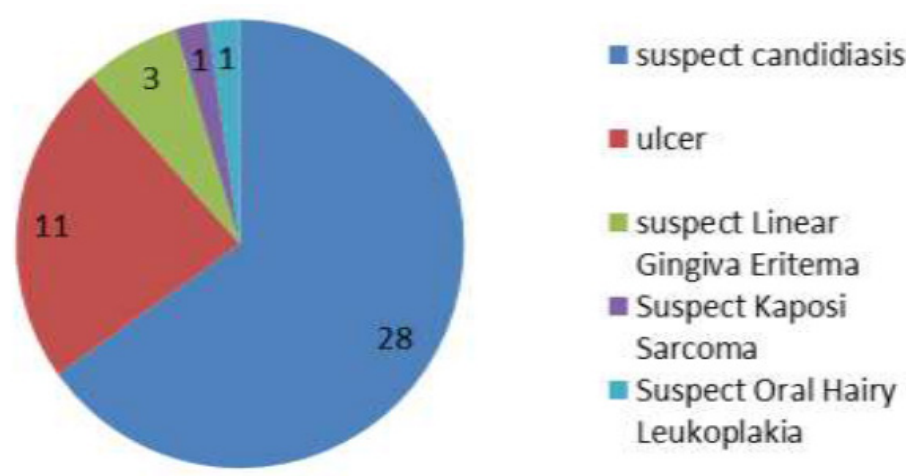

Figure 1 The Discovered of Oral Cavity Lesions

ences between respondents with good sexual behavior and bad sexual behavior towards the occurrence of oral lesions.

\section{DISCUSSION}

The most common feature of oral lesions found in this study was suspect candidiasis in 28 cases. This lesion is the highest prevalence of other lesions associated with sexually transmitted infections. The results of research conducted by Rahmayanti (2013) showed that oral lesions that are often found in HIV patients are oral candidiasis. A recent study conducted by Muralidharan (2018) showed that commercial sex workers in the City of Pune India found $31.4 \%$ of cases of oral hairy leukoplakia and $11.7 \%$ of cases of candidiasis. In a study conducted by Agita (2011) conducted at Dr. Kariadi Semarang showed $79 \%$ of candidiasis found in patients with HIV / AIDS. The HIV virus will attack the human immune system, especially CD-4 cells so that there can be a decrease in the immune system which will make it vulnerable to exposure to other diseases. Opportunistic infections generally occur when the CD4 cell count $<200$ cells / mm. ${ }^{11,12}$

The other lesions associated with STIs found in this study include ulcers, suspect Linear Gingival Erythema (LGE), suspect Kaposi sarcoma and Oral hairy leukoplakia. Ucler's case ranks the second highest prevalence found after suspect candidiasis. Ulcers can be caused by syphilis or gonorrhea. Ulcers caused by syphilis or called chancre are accompanied by indurations, redness on the edges and surface covered by serous fluid while ulcers caused by gonorrhea are characterized by a gray, dirty, and well-defined ulcer base. ${ }^{7,8}$

Linear Gingival Erythema is an infection in people with immunosuppressed characterized by red patches along the edge of the gingiva. Kaposi sarcoma caused by KSHV or Kaposi sarcoma herpes virus is a soft tissue malignancy derived from cell proliferation originating from blood vessel endothelial cells. Oral hairy leukoplakia is an epithelial cell hyperplasia disorder caused by the Epstein-Bar virus. ${ }^{13,14,15}$

The knowledge of CSWs in Argorejo Resocialization of Semarang city in this study was mostly quite good and the Chi-Square test results meant that there was no difference between the level of insufficient STI knowledge and the level of STI knowledge both of the occurrence of oral lesions. This shows that good knowledge does not affect the occurrence of oral cavity lesions and vice versa. This is because that CSWs who have good STI knowledge do not necessarily have good sexual behavior. Knowledge is one of the factors that can influence human behavior, but there are still many other factors that can affect human 
behavior, including economic and environmental factors. ${ }^{14}$

Knowledge of CSWs is strongly influenced by the presence of health workers and related non-governmental organizations (NGOs). These officers not only provide counseling as information that will be received by CSWs, but the information provided must also be able to provide clear and detailed information so that it can affect daily behavior. ${ }^{16}$

The sexual behavior of CSWs in Argorejo Resocialization of Semarang city in this study was largely quite good. But there are still CSWs Argorejo Resocialization of Semarang city who have bad sexual behavior. Chi-Square test results have the meaning that there are significant differences between good sexual behavior with bad sexual behavior towards the occurrence of oral cavity lesions. This shows that bad sexual behavior has a greater effect on the incidence of oral cavity lesions compared with good sexual behavior. The behavior of someone can be influenced by external factors, one of them is socio-economic factors. In a study conducted by Saefulloh et al. (2017) found that sexual behavior is influenced by economic factors, where the risks regarding health problems to be experienced are ignored by the society rather than having to experience difficulties in the family economy. The low socio-economic factors of CSWs make them want to behave whatever their clients want in the hope of receiving greater rewards so that despite having sufficient knowledge about STIs, there are still CSWs who acts bad sexual behavior and can potentially cause oral cavity lesions. ${ }^{17,} 18,19$

\section{CONCLUSION}

1. In this study found oral cavity lesions associated with STIs in CSWs in Sunan
Kuning localization of Semarang, there are Suspect Candidiasis, ulcers, Suspect Linear Gingival Erythema (LGE), Kaposi Sarcoma Suspension and Oral Hairy Leukoplakia.

2. The level of knowledge about STIs for commercial sex workers is not a risk factor for oral cavity lesions associated with STIs.

3. The sexual behavior of commercial sex workers is a risk factor for oral lesions associated with STIs.

\section{REFERENCES}

1. Aridawarni Y. Analisis Determinan Wanita Pekerja Seksual dengan Kejadian Infeksi Menular Seksual. Jurnal Obstretika Scientia. 2015 Nov $14 ; 2(1): 40-54$.

2. Kementerian Kesehatan. Survei Terpadu Biologis dan Perilaku. Jakarta: Kementerian Kesehatan Republik Indonesia. 2013.

3. Lestari, T. Kumpulan Teori Untuk Kajian Pustaka Penelitian Kesehatan. Yogyakarta: Nuha Medika. 2015.

4. Prasetio. A. Gambaran Pengetahuan Wanita Pekerja Seks (WPS) Tentang Penyakit Gonorhoe di Wilayah Kerja Puskesmas Pangandaran Kabupaten Pangandaran Tahun 2016. Skripsi (S.Kep). Sekolah Tinggi Ilmu Kesehatan Muhammadiyah Ciamis. 2016.

5. Raisyifa R, Khaidir M, Reflita R. Faktor-Faktor yang Berhubungan Dengan Tindakan Pencegahan Infeksi Menular Seksual Pada Pekerja Seks Komersial Di Lokalisasi Teleju Pekanbaru. Jurnal Kesehatan Masyarakat Andalas. 2009 Sep 1;4(1):5-12.

6. Ida, A., 2015. Identifikasi Agen Penyebab Infeksi Menular Seksual. , pp.15-21. Jurnal Skala Husada Volume 12 Nomor 1. April 2015 : $15-21$

7. Scully C. Medical Problems in Dentistry E-Book. Elsevier Health Sciences; 2010 Feb 8.

8. Prabhu SR, Kohli A, Rao CB. HIVIAIDS in dental practice. Handbook for dental practitioners. A publication of the dental council of India. 2007

9. Badan Pusat Statistik Provinsi Jawa Tengah. Jumlah Kasus HIVIAIDS, IMS, DBD, Diare, TB, dan Malaria Menurut Kabupaten/Kota di Provinsi Jawa Tengah, 2015. Badan Pusat Statistik Provinsi Jawa Tengah. terdapat di: https://jateng. bps.go.id/statictable/2016/08/22/1308/jumlahkasus-hiv-aids--ims--dbd--diare--tb--dan-malaria-menurut-kabupaten-kota-di-provinsi-jawa-tengah--2015.html. 2016 [15 Januari 2018]. 
10. Ariyani, N. dan Yusuf, A. Peranan Kader Kesehatan Dalam Pembinaan Wanita Pekerja Seks (WPS) di Lokalisasi Sunan Kuning. Journal of Non Formal Education and Community Empowerment. 2014; 3(2):36-43.

11. Muralidharan S, Acharya A, Sevekari T, Wadwan S, Joglekar NR, Margabandhu S. Prevalence of soft-tissue lesions among women in sex work in the red light area of Pune, India: A cross-sectional survey. Journal of International Society of Preventive \& Community Dentistry. 2018 May;8(3):218.

12. Back-Brito GN, El Ackhar VN, Querido SM, dos Santos SS, Jorge AO, de Macedo Reis AD, Koga-Ito CY. Staphylococcus spp., Enterobacteriaceae and Pseudomonadaceae oral isolates from Brazilian HIV-positive patients. Correlation with CD4 cell counts and viral load. Archives of oral biology. 2011 Oct 1;56(10):1041-6.

13. Aškinytè $D$, Matulionytè $R$, Rimkevičius $A$. Oral manifestations of HIV disease: A review. Stomatologija. 2015 Jan;17(1):21-8.

14. Sari KE, Saraswati PD, Suryana IK. Sarkoma Kaposi pada ODHA. CDK-253/ vol. 44 no. 6 th. 2017
15. Pujiastuti AT, Murtiastutik D. Oral Hairy Leukoplakia in Patient with HIVIAIDS. Berkala Ilmu Kesehatan Kulit dan Kelamin. 2016 Sep 19;28(1):71-7.

16. Pangaribuan, S.M. \& Mardiah, W. Gambaran Tingkat Pengetahuan Wanita Pekerja Seks Komersial Tentang Infeksi Menular Seksual. Jurnal Pendidikan Keperawatan Indonesia. 2017; 3(2):175-181.

17. Saefulloh, M., Wayunah \& Husnaniyah, D. Hubungan Harga Diri dengan Perilaku Seksual pada Penderita HIV AIDS di Kabupaten Indramayu. Jurnal Pendidikan Keperawatan Indonesia. 2017; 3(2):131-138.

18. Sarwono, S.W. Psikologi Remaja. ed ke-1. Jakarta: Rajawali Pers. 2016; 174-205.

19. Notoatmodjo S. Promosi kesehatan dan perilaku kesehatan. Jakarta: Rineka Cipta. 2012:45-62. 